\title{
Epidemiology, pattern and prevalence of alcohol consumption in India: need for public health action
}

\author{
Jagadeesan S.*, Pranav Patel
}

Department of Medicine, Vardhman Mahavir Medical College and Safdarjung Hospital, New Delhi, India

Received: 01 December 2020

Revised: 08 March 2021

Accepted: 09 March 2021

*Correspondence:

Dr. Jagadeesan S.,

E-mail: drjagadeesh1993@gmail.com

Copyright: (C) the author(s), publisher and licensee Medip Academy. This is an open-access article distributed under the terms of the Creative Commons Attribution Non-Commercial License, which permits unrestricted non-commercial use, distribution, and reproduction in any medium, provided the original work is properly cited.

\begin{abstract}
As we enter the year 2021, health and population related data related to the pattern, prevalence and epidemiological dimensions of alcohol consumption and its harmful use in Indian sub-continent needs time bound update. A nonsystematic narrative review was attempted to identify consistent scientific and gray literature on the prevalence, pattern and repercussions on the alcohol consumption status among Indian adults and children. As the nation has no unified data system on the substance use behaviour of it's residents, the review involved inclusion of the latest research articles from each state/ union territory being collected from an active search from PubMed, Google scholar and Europe PMC. Prevalence of alcohol consumption in India ranged from $10 \%$ to $60 \%$ with a predominant male predilection in agreement with previous studies. Peer pressure was perceived to be the most influential factor in promoting alcohol use with social occasions, urban background, family celebrations and 'staying away from family' playing additional role. Mere awareness of alcohol related complications was not assessed in most of the research items. Public health and administrative policies need to be focussed strongly reducing the free availability of alcohol among diverse geographical regions of the country. Policies and programmes are likely to be more effective if population heterogeneity is considered, and do address the wide range of modifiable risk and promoting factors at individual, community and social levels. Bringing public awareness with conventional and newer digital media will be contributive for both social and national productivity.
\end{abstract}

Keywords: Alcohol, Dependence, Prevalence, Public Health, Intervention

\section{INTRODUCTION}

Liquor has been in use in human communities since time immemorial. Alcoholic beverages were processed and devoured in almost all parts of the globe even before the british colonial expansion that has changed the cultural position of alcohol nearly far and wide. ${ }^{1}$ Multiple advanced forms of liquor were made current, and a commodity made at a domiciliary and community level was progressively transformed into an industrial product available round the clock with omnipresence. As part of the present day of globalisation, this course continues in a rising trend in developing nations. In the context of India, alcoholic beverages were known from ancient Vedic period, being used for adoration purposes, siddha and ayurvedic preparations, and generally taken as a tranquilizer. ${ }^{2}$ Universally, harmful use of alcohol leads on to a mortality of around 3.3 million deaths per annum (5.9\% of all causes of mortality), and $5.1 \%$ of the global burden of disease is strongly related to liquor consumption. ${ }^{3}$ Meanwhile accelerated globalization and economic liberalization are changing the social fabric and organizational structure of the Indian society and thus have a high impact on drinking patterns and cultures in the state as well. This article reviews literature on alcohol 
use in India and the need for public health plan, action or intervention in multiple dimensions.

\section{PATTERN AND PREVALENCE OF ALCOHOL ABUSE AND RELATED ILLNESS}

India is a diverse nation with hefty variation in climate, vegetation, natural resources, culture and traditions. This variegation is also echoed in the types of alcoholic beverages prepared, procured and used up with assorted cultural meaning associated with liquor use. The most common forms of alcoholic beverages available are arrack (fermentation of rice/paddy or wheat), toddy (wine from palm), country liquor (arrack), illicit liquor, Indian made foreign liquor (IMFL), beer and imported liquor. ${ }^{4}$ According to WHO, traditional alcoholic beverages viz., arrack, toddy, country liquor contain about 20 to $40 \%$ of alcohol, whereas it is as high as $56 \%$ in illicit liquor thus making the latter a big menace to the country's health. Ingredients used in illicit liquor production are akin to those used in country liquor manufacture; yet, illicit liquor is more often adulterated with industrial methylated spirit and other adulterants posing huge detrimental effects on health. Adding on to the fire, illicit liquor is relatively cheaper than the licensed country liquor and thus more rampant among urban and rural poor community making them more vulnerable. ${ }^{5}$

Table 1: Alcohol per capita (+15) consumption (in litres of pure alcohol). ${ }^{6}$

\begin{tabular}{|llll|}
\hline & $\begin{array}{l}\text { Average } \\
\mathbf{2 0 0 3 - 0 5}\end{array}$ & $\begin{array}{l}\text { Average } \\
\mathbf{2 0 0 8 - 1 0}\end{array}$ & Change \\
\hline Recorded & 1.6 & 2.2 & Increase \\
\hline Unrecorded & 2.0 & 2.2 & Increase \\
\hline Total & 3.6 & 4.3 & Increase \\
\hline Total male/female & & $8.0 / 0.5$ & \\
\hline $\begin{array}{l}\text { South East Asian } \\
\text { region }\end{array}$ & 2.9 & 3.5 & \\
\hline
\end{tabular}

In South-east Asian region, an increase in per capita pure alcohol consumption by over 50\% between 1980 and 2000 was reported. Not surprisingly, per capita purealcohol consumption has escalated in an alarming way by $106.7 \%$ between 1970-1972 and 1994-1996 in India. Travelling in the same trend, comprehensive global burden of disease and injury attributable to alcohol abuse in terms of disability adjusted life years (DALYs) has reached $5.1 \%$. Global information system on alcohol and health (GISAH) reports approximately 3.3 million deaths (5.9\% of all deaths) annually attributable to the harmful use of alcohol. ${ }^{6,7}$ The following data of WHO indicates the rising crisis of alcohol use or abuse in India in the past decade (Table 2-3). ${ }^{8-35}$

\section{CONSEQUENCES OF ALCOHOL ABUSE}

The issue of alcohol abuse in India is deeply rooted and has continued to affect not only health but also the social and economic well being of the youthful population and thus circumloculatorily the whole nation's productivity. In view of WHO factsheet, roughly 200 diseases and injury conditions have shown causal relationship with harmful use of alcohol, not all cases detrimentally. ${ }^{36}$ Not only quantity of liquor intake, but also patterns and trends of alcohol consumption, especially irregular heavy drinking, have been shown to be a deciding factor in multiple disorders. In almost all alcohol related disorders, a dose-response relationship to volume of alcohol consumption with risk of the disease increasing with increasing quantity of alcohol consumed has been evident in multiple studies with few exceptions viz., cardiovascular arena of disorders, notably coronary artery heart disease (CAHD) and cerebro-vascular accidents/CVA (stroke), type-2 diabetes mellitus, and unintentional injuries, wherein other dimensions of consumption than average quantity of consumption play a deciding role in determining outcome. ${ }^{37}$

\section{ALCOHOL HARM PARADOX}

In common understanding, economically weaker sections consume relatively less alcohol in quantity overall but pose a significantly elevated levels of liquor-attributable risks the wealthier counterparts. This has been termed the 'alcohol harm paradox'.38

\section{ALCOHOL AND LIVER}

Chronic liver diseases of any origin always have a poor outcome worldwide in terms of both morbidity and mortality. Keeping in view of the global demographic transition towards life style disorders, India being its epicentre of change, started a silent epidemic of Alcohol related liver disorders and non-alcoholic fatty liver diseases (NASH).$^{38}$ More worrisome is to find that, a stabilization for the past two to three decades in pure alcohol intake in economically developed nations, wherein a highly inimical tendency is being proclaimed from the struggling Asian and African nations (most chances of being underestimated because of poor reporting and surveillance systems). This is evident in a hospital based multi-centric study done in the peninsular India by Mukherjee PS et al on the pattern of chronic liver diseases $(n=13014)$, showed about $30.4 \%$ of cases were alcohol related, followed by infective causes and NASH.

In 2012, global alcohol report of WHO proclaimed that, age standardised death rates (ASDR) of 39.5 per 1 lakh population and 19.6 per one lakh population were owing to alcohol related liver diseases (cirrhosis of liver). In view of of negligent national data on transplantation and their causal skeleton, extrapolation from series from multiple transplant centres all over the country revealed, hepatitis $\mathrm{C}$ and alcoholic cirrhosis as the major indications for the same posing both health and economic burdens on the community and the country. ${ }^{3}$ 
Table 2: Alcohol consumption pattern in India.

\begin{tabular}{|c|c|c|c|c|c|c|c|}
\hline $\begin{array}{l}\text { Ref. } \\
\text { No. }\end{array}$ & Study site & Sample size & $\begin{array}{l}\text { Prevalence } \\
(\%)\end{array}$ & $\begin{array}{l}\text { Mean age of } \\
\text { starting } \\
\text { alcohol use } \\
\text { (years) }\end{array}$ & $\begin{array}{l}\text { Reason for } \\
\text { intake }\end{array}$ & $\begin{array}{l}\text { Major type } \\
\text { of alcohol }\end{array}$ & $\begin{array}{l}\text { Frequency } \\
\text { of intake } \\
\text { (major) }\end{array}$ \\
\hline 8 & $\begin{array}{l}\text { Sub-urban } \\
\text { Delhi }\end{array}$ & $\begin{array}{l}110 \text { male } \\
\text { adolescents }\end{array}$ & 55.6 & $13 \pm 3.5$ & Peer pressure & - & $\begin{array}{l}1-2 \\
\text { times/month }\end{array}$ \\
\hline 2 & $\begin{array}{l}\text { Rural } \\
\text { Puducherry }\end{array}$ & $\begin{array}{l}850 \text { adults of } \\
\text { any age above } \\
18 \text { years }\end{array}$ & 9.7 & $16-20$ & Pain $>$ tiredness & Beer & - \\
\hline 9 & $\begin{array}{l}\text { Bagalkot, } \\
\text { Karnataka }\end{array}$ & $\begin{array}{l}395 \text { medical } \\
\text { students }\end{array}$ & 20.5 & $18.32 \pm 2.84$ & $\begin{array}{l}\text { Social } \\
\text { occasions }\end{array}$ & - & - \\
\hline 10 & North Goa & $\begin{array}{l}732 \text { male } \\
\text { habitual } \\
\text { drinkers, aged } \\
18 \text { to } 49 \text { years }\end{array}$ & $\begin{array}{l}62.3 \\
\text { (monthly } \\
\text { once or } \\
\text { more times) }\end{array}$ & - & - & - & $\begin{array}{l}\text { Monthly } \\
\text { once }\end{array}$ \\
\hline 11 & $\begin{array}{l}\text { Guwahati, } \\
\text { Assam }\end{array}$ & $\begin{array}{l}680 \text { school } \\
\text { students }\end{array}$ & 36 & $13-16$ & $\begin{array}{l}\text { Social } \\
\text { occasions }\end{array}$ & Beer & - \\
\hline 12 & $\begin{array}{l}\text { Mumbai, } \\
\text { Maharashtra }\end{array}$ & $\begin{array}{l}220 \text { adults } \\
\text { aged } \geq 45 \text { years }\end{array}$ & 18.8 & - & Habit & $\begin{array}{l}\text { Country } \\
\text { liqour }\end{array}$ & Once/ week \\
\hline 13 & $\begin{array}{l}\text { Rohtak, } \\
\text { Haryana }\end{array}$ & $\begin{array}{l}4,691 \text { subjects } \\
\text { aged } \geq 14 \text { years }\end{array}$ & 19.78 & $20.3 \pm 5$ & $\begin{array}{l}\text { Sociable } \\
\text { reason }\end{array}$ & $\begin{array}{l}\text { Country } \\
\text { liquor }\end{array}$ & - \\
\hline 14 & $\begin{array}{l}\text { Udupi, } \\
\text { Karnataka }\end{array}$ & 825 fishermen & 45.6 & - & $\begin{array}{l}\text { Job related } \\
\text { stress }\end{array}$ & - & - \\
\hline 15 & $\begin{array}{l}\text { Srikot, } \\
\text { Uttarakhand }\end{array}$ & $\begin{array}{l}155 \text { village } \\
\text { residents }\end{array}$ & 16.8 & & Male gender & - & $\begin{array}{l}\text { Once } \\
\text { weekly }\end{array}$ \\
\hline 16 & $\begin{array}{l}\text { Calicut } \\
\text { (Kerala) \& } \\
\text { Chirala } \\
\text { (Andhra } \\
\text { Pradesh) }\end{array}$ & $\begin{array}{l}63 \text { female sex } \\
\text { workers }\end{array}$ & 96 & - & $\begin{array}{l}\text { Sex related to } \\
\text { profession }\end{array}$ & Rum & $\begin{array}{l}\text { Almost } \\
\text { daily }\end{array}$ \\
\hline 17 & $\begin{array}{l}\text { Bandardewa, } \\
\text { Arunachal } \\
\text { Pradesh }\end{array}$ & $\begin{array}{l}312 \text { village } \\
\text { inhabitatants } \\
\text { of age }>10 \\
\text { years }\end{array}$ & 36.5 & $21.6 \pm 2$ & Peer pressure & IMFL & $\begin{array}{l}\text { Twice } \\
\text { weekly }\end{array}$ \\
\hline 18 & $\begin{array}{l}\text { Andaman } \\
\text { Nicobar } \\
\text { Islands }\end{array}$ & $\begin{array}{l}18,018 \\
\text { islanders of } \\
\text { age } \geq 14 \text { years }\end{array}$ & $\begin{array}{l}35 \text { (males) } \\
6 \text { (females) }\end{array}$ & - & - & $\begin{array}{l}\text { Homebrews } \\
\text { (Toddy, } \\
\text { Handia) }\end{array}$ & $\begin{array}{l}\text { Once } \\
\text { weekly or } \\
\text { more }\end{array}$ \\
\hline 19 & $\begin{array}{l}\text { Ernakulam, } \\
\text { Kerala }\end{array}$ & $\begin{array}{l}7650 \text { school } \\
\text { students of age } \\
12-19 \text { years }\end{array}$ & 15 & $13.6 \pm 2.4$ & $\begin{array}{l}\text { Family } \\
\text { members }\end{array}$ & - & $\begin{array}{l}\text { Once/twice } \\
\text { in } 3 \text { months }\end{array}$ \\
\hline 20 & $\begin{array}{l}\text { Sehore, } \\
\text { Madhya } \\
\text { Pradesh }\end{array}$ & 3220 adults & $\begin{array}{l}23.8 \text { (males) } \\
0.6 \\
\text { (females) }\end{array}$ & - & - & - & - \\
\hline 21 & Punjab & $\begin{array}{l}13,925 \text { adults } \\
\text { of age } 11-60 \\
\text { years }\end{array}$ & 10.9 & - & - & - & - \\
\hline 22 & $\begin{array}{l}\text { Karauli, } \\
\text { Rajasthan }\end{array}$ & $\begin{array}{l}213 \text { mine } \\
\text { workers } \\
203 \text { non } \\
\text { miners }\end{array}$ & $\begin{array}{l}26 \text { (miners) } \\
10.3 \text { (Non- } \\
\text { miners) }\end{array}$ & 10 & - & - & - \\
\hline 23 & $\begin{array}{l}\text { Lucknow, } \\
\text { Uttar Pradesh }\end{array}$ & 3437 adults & 4.2 & - & - & - & - \\
\hline 24 & $\begin{array}{l}\text { Birbhum, } \\
\text { West Bengal }\end{array}$ & 36,611 adults & $\begin{array}{l}19 \text { (males) } \\
2.4 \\
\text { (females) }\end{array}$ & - & Peer pressure & $\begin{array}{l}\text { Home-made } \\
\text { rice beers }\end{array}$ & - \\
\hline
\end{tabular}


Table 3: Prevalence studies on alcoholism in India (states-wise).

\begin{tabular}{|c|c|c|c|c|}
\hline $\begin{array}{l}\text { Ref. } \\
\text { No. }\end{array}$ & Site of the study & Sample size & Study participants & $\begin{array}{l}\text { Prevalence } \\
(\%)\end{array}$ \\
\hline 25 & $\begin{array}{l}\text { Five Indian states viz., } \\
\text { Andhra Pradesh, } \\
\text { Maharashtra, } \\
\text { Madhya Pradesh, West } \\
\text { Bengal, and Kerala }\end{array}$ & 6,088 & $\begin{array}{l}\text { Community based study involving } \\
\text { Urban and rural dwellers of any age } \\
\text { above } 18 \text { years }\end{array}$ & 38.6 \\
\hline 26 & Bikaner, Rajasthan & 328 & Persons above age of 10 & 10.9 \\
\hline 24 & Birbhum, West Bengal & 36,611 & Adults of any age & $\begin{array}{l}19 \text { in men, } \\
2.4 \text { in women }\end{array}$ \\
\hline 20 & $\begin{array}{l}\text { Sehore District, } \\
\text { Madhya Pradesh }\end{array}$ & 3,220 & Adults of age $\geq 18$ years & 23.8 \\
\hline 27 & Ludhiana District, Punjab & 1,732 & $\begin{array}{l}\text { Individuals aged } 15 \text { years and above in } \\
\text { the study area }\end{array}$ & 93.1 \\
\hline 18 & $\begin{array}{l}\text { Andaman Nicobar islands, } \\
\text { Union Territory }\end{array}$ & 18,018 & Subjects of age $\geq 14$ years were chosen & $\begin{array}{l}35 \text { in males } \\
6 \text { in females }\end{array}$ \\
\hline 8 & Sub-urban Delhi & 110 & Male adolescents of age 11-19 years & 55.6 \\
\hline 28 & Dibrugarh, Assam & 650 & $\begin{array}{l}\text { Tea plantation workers of age 15-24 } \\
\text { years }\end{array}$ & 32.2 \\
\hline 29 & Buguda, Odisha & 431 & $\begin{array}{l}\text { Individuals with age } 18 \text { years and } \\
\text { above }\end{array}$ & 38 \\
\hline 30 & $\begin{array}{l}\text { Rural and tribal belts of } \\
\text { Central Maharshtra }\end{array}$ & 4,711 & Adults aged 30 years and above & 23 \\
\hline 31 & Dimapur, Nagaland & 100 & Adolescents of age 10-19 years & 46.3 \\
\hline 32 & $\begin{array}{l}\text { Eight medical colleges in } \\
\text { India }\end{array}$ & $\begin{array}{l}150 \mathrm{UG} \text { and } 55 \mathrm{PG} \\
\text { students from each } \\
\text { college }\end{array}$ & $\begin{array}{l}\text { Students pursuing MBBS or Post } \\
\text { Graduation in the selected medical } \\
\text { colleges }\end{array}$ & $\begin{array}{l}16.6 \text { in } \mathrm{UG} \\
31.5 \text { in } \mathrm{PG}\end{array}$ \\
\hline 19 & Ernakulam, Kerala & 7,560 & $\begin{array}{l}\text { School students in the age group of } 12- \\
19 \text { years }\end{array}$ & 15 \\
\hline 33 & Vellore, Tamil Nadu & 345 & $\begin{array}{l}\text { Aged } 18 \text { years and above in } \\
\text { kanniyambadi block, Vellore }\end{array}$ & 46.7 \\
\hline 34 & $\begin{array}{l}\text { West Kameng, Arunachal } \\
\text { Pradesh }\end{array}$ & 1,660 & Adults of any age & 50.2 \\
\hline 35 & $\begin{array}{l}\text { Theni, } \\
\text { Tamil Nadu }\end{array}$ & 500 & School students of age $15-17$ & 31.06 \\
\hline
\end{tabular}

\section{ALCOHOL AND ADDICTIVE BEHAVIOUR}

Pattern of abusive and addictive nature of alcohol and other substances have a very notorious behaviour to change with time. With a handful of states flagging prohibition on liquor, the free-flowing alcohol shops around the tiniest streets pose a great danger for the younger generations to fall prey for dependence and subsequently addiction. There is paucity for national policy on alcohol addiction and not surprisingly a country wide data on alcohol related mental illnesses though the prevalence ballooning day by day. In an interview based cross-sectional study conducted by Chavan et al in Chandigarh $(\mathrm{N}=59470)$ found about 69 per 1000 population was either drug or alcohol dependant in nature. $^{39}$

A similar study conducted at Bengaluru, by Gururaj et al recorded a prevalence of 320 per 1000 alcohol users $(\mathrm{N}=28,507)$ which escalated from 90 per 1000 population by the same investigator at the same region two years back. ${ }^{40}$ Though the alcohol consumption rate has come down in a meagre quantity as per the National family health survey data of 2005-06 and 2015-16, sill miles to go in getting away with alcohol dependence. In a bird's eye view, It is evident that over 2006 to 2016, consumption of alcohol among men has fallen sharply in central and Northern states viz., Madhya Pradesh, Bihar, Uttarakhand, Haryana, West Bengal leaving peninsular India far behind in a bad shape. ${ }^{41}$

\section{OTHER SEQUELAE OF ALCOHOL}

Alcohol-related injuries have always been worrisome in India alike the western counterparts, where in the effective tackling and treatment of traumatic injuries is relatively not appreciable owing to the lacunae in skilled man power, basic infrastructure, efficient imposition of laws, and ill-fitting public health policies. In the subcontinent, alcohol abuse has a disproportionately high 
correlation with (RTA) road traffic accidents and intentional self-harm and implicating as high as 20 per cent of traumatic brain injuries. ${ }^{42}$ A systematic review by Das A et al reiterated the aforesaid finding that a significant proportion of injured or killed road users in India had used alcohol before the accident. ${ }^{43}$ Esser MB et al (2015) found about $83 \%$ of the study participants proclaimed to have had at least a single alcohol-related violence from a heavy drinker in their lives either from the spouse or father for that matter concerned, and not surprising, $50 \%$ of the victims reported either emotional (verbal) violence or neglect and $25 \%$ and $6 \%$ proclaimed to have experienced physical violence and sexual violence respectively. ${ }^{44,45}$ A study from Eastern India encompassing Jharkhand, Odisha and West Bengal found that women with alcoholic husbands experienced 5-13 times higher risk of domestic violence, varying by risk for physical, psychological and sexual dimensions. ${ }^{45}$ Similarly multiple studies from India have found domestic intentional injuries and violence to be ranging from $18 \%$ to $70 \%$ with variation in the study methodology and tools applied. ${ }^{46,47}$ A steep fall in 'evermarried women who have ever experienced spousal violence' in National family health survey 2015-16 to $28.8 \%$ from $37.2 \%$ (of 2005-06 NFHS-3 data) is to be elated. ${ }^{41}$

Another notable factor that requires special mention is about the 'country liquor' or adulteration of methanol with ethanol (in view of cheapness of methanol and its ability to give early euphoria or kick to chronic drinkers). India is a perennial landscape for toxic methanol poisoning, a recent incident that cost about 102 deaths in Malwani, Mumbai city, Maharashtra and 2017 Ramgopalpur incident in West Bengal with at least six citizens kicking the bucket due to spurious liquor. ${ }^{48}$ The campus of interest in all these cases is that the major cause of fatalities in almost every Methanol poisoning is due lack of awareness amongst the habitual drinkers and late arrival at the hospital after full blown development of metabolic acidosis, dyselectrolemia and even coma. ${ }^{49}$

In a meta-analysis on alcohol related suicidal ideation by Darvishi et al, at a global level including India based studies, recorded a significant association between suicidal ideation and alcohol use disorder with OR of 1.86 (CI: $1.38-2.35)$ and suicide attempt $(\mathrm{OR}=3.13 ; 95 \%$ CI: $2.45,3.81)$; and completed suicide $(\mathrm{OR}=2.59 ; 95 \%$ CI: $1.95,3.23) .{ }^{48,49}$ In a countrywide survey by Pandey et al, to find the correlation of alcohol use with sexually transmitted infection amongst country men found a blanket prevalence of about $2.5 \%$ with $26 \%$ amidst them using alcohol. The men who consumed alcohol had higher prevalence of STI $(3.6 \%$; 95\% CI: 2.9-5.1) than those who did not consume alcohol $(2.1 \%$; $95 \%$ CI: $1.5-$ 2.6). This statistical information is reinforced by a similar research by Saggurti et al in 2010 in Mumbai, putting daily alcohol drinkers four times more likely than those not consuming alcohol in the last month to have gonorrhoea (NG) and chlamydia (CT) infection and three times more likely to have had a past history of exposure to herpes simplex virus-2 (HSV-2) and/or syphilis as determined by biological testing. ${ }^{50}$

\section{CONCLUSION}

Does India need an alcohol ban? Adding on to the way ahead of an alcohol-free state, apex court of India ruled (December 15, 2016) a ban on State and Union Territories from granting licences for the sale of alcohol alongside the national and state highways county-wide, noting that drunken driving was the main culprit behind a large number of road traffic accidents (RTA) in the country is indeed on a 'res extra commercium' basis is heartwelcoming. Holding drug de-addiction programme (DDAP) of ministry of health and family welfare resulting in establishment of National drug dependence treatment centre (NDDTC) at AIIMS, New Delhi and similar centres for de-addiction is warranting to overcome this menace. Multicentric studies have established that heavy alcohol consumption increases the risk of blood pressure, cerebro-vascular accident (stroke) and cirrhosis of liver as discussed in the article earlier. It gains more attraction especially in terms of a developing nation like India, wherein people tend to drink so heavily. In this scenario, alcohol dependence/addiction tends to have both adverse health and socio-economic corollary, evading the vital resources away from basic necessities such as nutrition/food, shelter, clothing and schooling of the off springs. It also affects the welfare of other household members, especially the children and women dependant on the domiciliary head for the preceding. It is a wellknown fact that the momentum of progress of a reserved who are dependent on the surplus it generates. Being an alcoholic rich nation, it is hard for the country to prosper both in economic affairs and in world health platform too. It is clear that a non pendular balance to be achieved in recreational use and renaissance of the public health and well-being.

\section{ACKNOWLEDGEMENTS}

Authors are thankful and appreciate the Centre for Community Medicine (CCM), All India Institute of Medical Sciences, New Delhi for guidance.

Funding: No funding sources

Conflict of interest: None declared

Ethical approval: Not required

\section{REFERENCES}

1. Abbey A, Smith MJ, Scott RO. The relationship between reasons for drinking alcohol and alcohol consumption: An interactional approach. Addict Behav. 1993;18(6):659-70.

2. Ramanan Vv, Singh S. A study on alcohol use and its related health and social problems in rural Puducherry, India. J Fam Med Prim Care. 2016; 5(4):804. 
3. Hydes T, Gilmore W, Sheron N, Gilmore I. Treating alcohol-related liver disease from a public health perspective. J Hepatol. 2019;70(2):223-36.

4. Chattopadhyay S, Fielding J. India: alcohol and public health. Addiction. 2005;100(8):1051-6.

5. Sharma HK, Tripathi BM, Pelto PJ. The evolution of alcohol use in India. AIDS Behav. 2010;14(S1):8-17.

6. Bennett LA, Gureje O. Alcoholic beverage consumption in India, Mexico, and Nigeria. Res World. 1998;22(4):10.

7. Manthey J. Quantifying the global contribution of alcohol consumption to cardiomyopathy. J Hepatol. 2017;9(2):45-9.

8. Daniel L, Krishnan G, Gupta S. A study to assess the prevalence and pattern of substance use among male adolescents in suburban area of Delhi. Indian J Soc Psychiatry. 2017;33(3):208.

9. A Cross-sectional study on pattern of alcohol consumption and body mass index among health institution students in Bagalkot. Available at: http://jcdr.net/article_fulltext.asp?issn=0973-

$709 x \&$ year $=2015 \&$ volume $=9 \&$ issue $=12 \&$ page $=$ LC 0 $6 \&$ issn $=0973-709 x \& i d=6905$. Accessed on 20 November 2020.

10. Pillai A, Nayak MB, Greenfield TK, Bond JC, Nadkarni A, Patel V. Patterns of alcohol use, their correlates, and impact in male drinkers: a populationbased survey from Goa, India. Soc Psychiatry Psychiatr Epidemiol. 2013;48(2):275-82.

11. Bhagabati D, Das B, Das S. Alcohol consumption in India- An epidemiological review. J Family Med Prim Care. 2020;9(1):49-55.

12. Gupta PC. Alcohol consumption among middle-aged and elderly men: a community study from western India. Alcohol. 2003;38(4):327-31.

13. Khanna P, Vohra AK, Rajput R. Prevalence and pattern of alcohol and substance abuse in urban areas of rohtak city. Indian J Psychiatry. 2002;44(4):34852.

14. Rane PP, Narayanan P, Binu V, Unnikrishnan B. Prevalence of Tobacco and Alcohol Consumption among Fishermen in Udupi Taluk' Karnataka, India: a Cross-Sectional Study. Asian Pac J Cancer Prev. 2016;17(4):1733-7.

15. Rautela Y, Gupta A, Singh AK, Reddy BV. Smoking and alcoholism among adult population and its association with outlet density in a hilly area of North India. J Prev Med Hyg. 2019;6:E361 Pages.

16. Heravian A, Solomon R, Krishnan G, Vasudevan CK, Krishnan AK, Osmand T, et al. Alcohol consumption patterns and sexual risk behavior among female sex workers in two South Indian communities. Int J Drug Policy. 2012;23(6):498-504.

17. Hazarika NC, Biswas D, Phukan RK, Hazarika D, Mahanta J. Prevalence and pattern of substance abuse at bandardewa, a border area of assam and arunachal pradesh. Indian J Psychiatry. 2000;42(3):262-266.

18. Manimunda SP, Sugunan AP, Thennarasu K, Pandian D, Pesala KS, Benegal V. Alcohol consumption, hazardous drinking, and alcohol dependency among the population of andaman and Nicobar Islands, India. Indian J Public Health. 2017;61(2):8.

19. Jaisoorya TS, Beena KV, Beena M, Ellangovan K, Jose DC, Thennarasu K, et al. Prevalence and correlates of alcohol use among adolescents attending school in Kerala, India. Int J Drug Policy 2015;7:521-9.

20. Rathod SD, Nadkarni A, Bhana A, Shidhaye R. Epidemiological features of alcohol use in rural India: a population-based cross-sectional study. BMJ Open. 2015;5(12):e009802.

21. Avasthi A, Basu D, Subodh BN, Gupta PK, Sidhu BS, Gargi PD, et al. Epidemiology of substance use and dependence in the state of Punjab, India: Results of a household survey on a statewide representative sample. Asian J Psychiatry. 2018;33:18-29.

22. Ahmad A, Rahman I, Alagarajan M. Prevalence and pattern of substance use among sandstone mine workers in Rajasthan, India. Clin Epidemiol Glob Health. 2020;8(2):570-5.

23. Kumar S. Epidemiology of substance abuse in the population of Lucknow. J Oral Biol Craniofacial Res. 2015;6:59-65.

24. Sidhu BS, Gargi PD. Alcohol use-related problems among a rural Indian Population of West Bengal: An application of the alcohol use disorders identification test (AUDIT). Alcohol. 2016;51(2):9.

25. Kumar K, Kumar S, Singh AK. Prevalence and socio-demographic correlates of alcohol consumption: Survey findings from five states in India. Drug Alcohol Depend. 2018;185:381-90.

26. Qureshi AA, Acharya R, Sharma G, Sethia R, Shekhawat K, Kawatra A. An epidemiological study to assess prevalence and behavior related to substance abuse among urban Bikaner population Rajasthan. Int J Community Med Public Health. 2017;4(9):3338.

27. Dube S, Chaudhary A, Mahajan R, Purohit R, Chaudhary S, Saluja N, et al. Chavan BS, Arun P, Bhargava R, Singh GP. Prevalence of alcohol and drug dependence in rural and slum population of Chandigarh: A community survey. Indian J Psychiatry. 2007;49(1):44-8.

28. Medhi G, Hazarika N, Mahanta J. Tobacco and alcohol use among the youth of the agricultural tea industry in Assam, INDIA. Southeast Asian J Trop Med Public Health. 2006;37(3):7.

29. Pati S, Swain S, Mahapatra S, Hussain M, Pati S. Prevalence, pattern, and correlates of alcohol misuse among male patients attending rural primary care in India. J Pharm Bioallied Sci. 2017;9(1):66.

30. Jonas JB, Nangia V, Rietschel M, Paul T, Behere P, Panda-Jonas S. Prevalence of depression, suicidal ideation, alcohol intake and nicotine consumption in rural central India. PLoS ONE. 2014;9(11):e113550.

31. Nuken A, Singh LL. Risk-taking Behaviors among Youth in Dimapur, Nagaland. J Pharm Bioallied Sci. 2013;3(3):12. 
32. Goel N, Khandelwal V, Pandya K, Kotwal A. Alcohol and tobacco use among undergraduate and postgraduate medical students in india: a multicentric cross-sectional study. Cent Asian J Glob Health. 2015;4(1):52-9..

33. John A, Barman A, Bal D, Chandy G, Samuel J, Thokchom M, et al. Hazardous alcohol use in rural southern India: nature, prevalence and risk factors. Natl Med J India. 2009;22(3):123-5.

34. Deswal BS, Jindal AK, Gupta KK. Epidemiology of Alcohol Use among Residents of Remote Hills of Arunachal Pradesh. Int J Community Med Public Health. 2006;31(2):3.

1. 35. Joy N, Vijaykumar $P$, Thapa S, Singh V, Raghava V, Seshadri T A. Study on prevalence of alcohol consumption among higher secondary school students in Theni district, Tamil Nadu. Int J Basic Clin Pharmacol. 2020;9(2):226.

35. Monteiro MG. The road to a world health organization global strategy for reducing the harmful use of alcohol. Cent Asian J Glob Health. 2011; 34(2):4.

36. Rehm J, Room R, Graham K, Monteiro M, Gmel G, Sempos CT. The relationship of average volume of alcohol consumption and patterns of drinking to burden of disease: an overview: Alcohol and global burden of disease. Addiction. 2003;98(9):1209-28.

37. Rossow I, Romelsjö A. The extent of the 'prevention paradox' in alcohol problems as a function of population drinking patterns. Alcohol. 2006;7:52-9.

38. Singh G, Chavan B, Arun P, Bhargava R. Prevalence of alcohol and drug dependence in rural and slum population of Chandigarh: A community survey. Indian J Psychiatry. 2007;49(1):44.

39. Gururaj G, Benegal V, Girish N, Kavita R. Alcohol use and implications for public health: Patterns of use in four communities. Indian $\mathrm{J}$ Community Med. 2010;35(2):238.

40. Dandona R, Pandey A, Dandona L. A review of national health surveys in India. Bull World Health Organ. 2016;94(4):286-96.

41. Hahn RA, Kuzara JL, Elder R, Brewer R, Chattopadhyay S, Fielding J, et al. Effectiveness of policies restricting hours of alcohol sales in preventing excessive alcohol consumption and related harms. Am J Prev Med. 2010;39(6):590-604.

42. Das A, Gjerde H, Gopalan SS, Normann PT. Alcohol, drugs, and road traffic crashes in india: a systematic review. Traffic Inj Prev. 2012;13(6):54453.

43. Esser MB, Gururaj G, Rao GN, Jayarajan D, Sethu L, Murthy P, et al. Harms from alcohol consumption by strangers in five Indian states and policy implications: Harms from alcohol consumption by strangers. Drug Alcohol Rev. 2017;36(5):682-90.

44. Babu BV, Kar SK. Domestic violence in Eastern India: Factors associated with victimization and perpetration. Public Health. 2010;124(3):136-48.

45. Stephenson R, Koenig MA, Ahmed S. Domestic Violence and Symptoms of Gynecologic Morbidity Among Women in North India. Int Fam Plan Perspect. 2006;32(04):201-8.

46. Hassan F, Sadowski LS, Bangdiwala SI, Vizcarra B, Ramiro L, De Paula CS, et al. Physical intimate partner violence in Chile, Egypt, India and the Philippines. Inj Control Saf Promot. 2004;11(2):1116.

47. D'Silva J. India's problem with toxic alcohol. BMJ. 2015;25:h4536.

48. Darvishi N, Farhadi M, Haghtalab T, Poorolajal J. Alcohol-related risk of suicidal ideation, suicide attempt, and completed suicide: A meta-analysis. Voracek M, editor. PLOS ONE. 2015;10(5): e0126870.

50. Saggurti N, Schensul SL, Singh R. Alcohol use, sexual risk behavior and stis among married men in Mumbai, India. AIDS Behav. 2010;14(S1):40-7.

Cite this article as: Jagadeesan S, Patel P. Epidemiology, pattern and prevalence of alcohol consumption in India: need for public health action. Int J Community Med Public Health 2021;8:2070-6. 